\title{
SECTORAL ANALYSIS ON THE IMPACT OF ISLAMIC BANKS ON THE MALAYSIAN ECONOMY
}

\author{
Imam Wahyudi Indrawan ${ }^{1}$ and Maya Puspa Rahman² \\ ${ }^{1}$ International Islamic University Malaysia, Malaysia, indrawan.imam@live.iium.edu.my. \\ ${ }^{2}$ International Islamic University Malaysia, Malaysia, mayapuspa@iium.edu.my.
}

\begin{abstract}
Malaysia is a well-known Islamic finance hub with a growth trend in its Islamic financial assets. The growth of the Malaysian economy since independence has also been commendable, with a rising contribution from Islamic banking and finance. This study offers a different perspective by undertaking a sectoral analysis on the impact of Islamic banks in Malaysia. It aims to fill the gap in the literature by investigating how Islamic bank financing (IBF) affects economic growth in Malaysia, both overall and at the sectoral level. Three sectors are observed in this study: agriculture, industry and services. Both long-run and short-run analyses are undertaken for the data period 2007Q1 to 2018Q4. The Autoregressive Distributed Lag (ARDL) method is utilised where IBF is found to significantly and positively affect the economic growth of Malaysia, at the overall and sectoral level. Nonetheless, there is a negative relationship in the agriculture sector and no cointegration in the industry sector. The results of this study are expected to provide insights for policymakers in encouraging more optimal Islamic financing to economic sectors in Malaysia.
\end{abstract}

Keywords: ARDL, Economic growth, Islamic bank financing, Malaysia, Sectoral analysis. JEL Classification: E44; G21; O41; O47.

\author{
Article history: \\ Received : October 27, 2018 \\ Revised : January 3, 2020 \\ Accepted : January 8, 2020 \\ Available online : February 28, 2020 \\ https://doi.org/10.21098/jimf.v6i1.1119
}




\section{INTRODUCTION}

\subsection{Background}

Islamic banking, the pioneer of Islamic finance, began as a response from the Muslim world for Sharia-compliant banking services, as an alternative to the interest-bearing banking system. Looking at the inadequate economic well-being that has resulted from the conventional economic system, Muslims around the globe have endeavoured to uncover the wisdom from classical Islamic teachings related to the economic system and apply it in the contemporary context. The conceptual development of Islamic banking initially began in the 1940s as an abstract concept (Khan \& Bhatti, 2008).

The Islamic banking industry has since developed rapidly, with 505 Islamic banks from 69 countries involved in the growing industry. Moreover, the global Islamic banking industry had current assets worth US\$ 1.7 trillion in 2017 and an average growth rate of $5 \%$ since 2012 , representing $71 \%$ of the assets of the global Islamic financial industry. The global Islamic banking industry is projected to be worth US\$ 2.4 trillion in 2023 (Thomson Reuters, 2018b).

Among the world's five top Islamic banking markets, Malaysia is the only non-Middle Eastern country, with total assets worth US\$ 201 billion in 2017 and 38 institutions providing Islamic banking services (Thomson Reuters, 2018b). This is unsurprising considering the pioneering role played by Malaysia in the Islamic banking industry, especially among South East Asian nations. Although Malaysia was not the first country to have established an Islamic bank, the enactment of the Islamic Banking Scheme in 1993 led to a rapid expansion of Islamic banks thanks to the provision of a legal standing for conventional banks to provide Islamic banking services within the name of "Islamic windows" (Nakagawa, 2009).

Islamic banking in Malaysia currently appears to be set on a growth trend. In 2018, Sharia-compliant financing grew by 10.5\% to RM668.7 billion, while the current share of Islamic financing increased from $34.9 \%$ in 2017 to $36.6 \%$ of the total banking sector financing. Moreover, the net profit before tax of Islamic banks grew by $14.8 \%$ to RM7.7 billion. This growth can be attributed to various factors, including additional financial assets for Islamic banks following the merger between an Islamic bank and a non-bank institution in early 2018 and growth in Islamic financing to households and businesses of $11.5 \%$ and $8.9 \%$ respectively (Bank Negara Malaysia, 2018).

The growing trend of Malaysia's Islamic banking industry sits in parallel to the country's economic growth. The Malaysian economy grew at the sterling rate of $4.7 \%$ in the fourth quarter of 2018 . According to statistical data reported by the Department of Statistics Malaysia (2019), the country has seen increasing economic growth during recent decades, accompanied by a low rate of unemployment (3.3\%). Services is the dominant sector in the Malaysian economy, with a $56 \%$ share and a $6.9 \%$ growth rate. This is followed by the manufacturing sector with a $22.8 \%$ share and $4.7 \%$ growth. The construction sector also experienced positive growth, at $2.6 \%$, with a $4.2 \%$ share. Growth in the mining and quarrying sector was slower, however, at $0.5 \%$, with a $7.9 \%$ share of the economy. Lastly, the agriculture sector experienced negative growth of $-0.4 \%$ and also with a $7.9 \%$ share.

Islamic banking, as part of Islamic finance, is expected to support economic growth. Normatively, Islamic principles, as the foundation of the Islamic banking 
system, place a strong emphasis on the direct and undetachable relationship between real and financial transactions (Kahf, 2007). In contrast to the interestbased conventional banking system, which is security-oriented in order to secure the capital and profit of the capital owner, Islamic banks, through schemes such as mudaraba and murabaha, have the potential to significantly enhance economic growth (Nakagawa, 2009). From a theoretical point of view from the finance-growth nexus, Islamic banking, as part of financial development, could help to strengthen economic growth by accommodating the needs for entrepreneurial actors with the aforementioned Islamic schemes. This is in line with the Schumpeterian theory of growth, which states that the banking system is vital to enhance economic development and income growth through the identification and financing of productive investment (Schumpeter, 1983).

\subsection{Objective}

Previous studies sought to investigate the nature of the relationship between economic growth and the development of Islamic finance in Malaysia (Furqani \& Mulyany, 2009; Kassim, 2016); however, none of them included sectoral analysis as the scope of the study. As Malaysia's economy has grown, certain sectors have experienced higher growth than others and have thus been accorded more attention by economic actors (including the financial institutions). The majority share of the services sector against the comparatively small size of the agriculture sector in Malaysia's economy is a sign of modernisation and progress in economic development (Todaro \& Smith, 2015). At the same time, the financial industry, including Islamic banking, may only benefit the dominant economic sector over the others, which potentially hinders the achievement of the VBI (ValueBased Intermediation) initiative taken by Bank Negara Malaysia (BNM). BNM's intention is for VBI, inter alia, to direct more optimal financing from Islamic banking to targeted economic sectors through entrepreneurship and community empowerment. Therefore, it is essential to consider the different dynamic behaviour among different economic sectors within the finance-growth nexus framework, and Islamic banking is no exception.

This study will aim to fill the literature gap by examining the impact and dynamics of Islamic banking on different sectors of Malaysia's economy (agriculture, industry and services) as well as the economy as a whole. The findings from this study have notable policy implications, whether Islamic banking has a positive or negative effect on the Malaysian economy, in the long run or the short run. Moreover, the inclusion of sectoral analysis in this study is expected to provide reasons to support or expand Islamic banking in each of the economic sectors observed in this study. Given that the VBI initiative is already underway, this study is expected to be an input for policymakers in determining the direction of Islamic banking within the development of Malaysia's economy.

Chapter 2 of this paper covers the literature review, consisting of the theoretical background and an explanation of the prior studies related to the financegrowth nexus, particularly the case of the Islamic banking industry. Chapter 3 covers the data specification, model development and method utilised to achieve the research objective. Chapter 4 contains the results for the models estimated 
and their robustness tests. Finally, chapter 5 concludes the study and offers recommendations for stakeholders in the Islamic banking industry in Malaysia, including regulators and bankers, and also for future research.

\section{LITERATURE REVIEW}

\subsection{Theoretical Background Finance-Growth Nexus}

Scholars have long observed the nexus between financial sector development and economic growth (later, the financial-growth nexus); however, the results have been somewhat inconclusive. Four main hypotheses have attempted to explain the financial-growth nexus. First, the supply-leading hypothesis, whereby financial development causes economic growth, has its roots in Schumpeter's (1983) argument about the role of the financial sector in supporting technological innovation. Second, the demand-driven hypothesis, where economic growth will demand a greater level of financial services to promote further growth. This hypothesis can be traced back to Robinson (1952) with his statement, "where enterprise leads, finance follows". Third, the mutually dependent hypothesis, in which the finance-growth nexus is typically reciprocal or bi-directional. This hypothesis was postulated by Patrick (1966) with the argument that in developing countries, the nexus is "supply-leading", while in more developed nations, "demand-driven" is dominant. Fourth, the neutrality hypothesis, which is a view by Lucas (1988) that the finance-growth nexus is an issue that has been overemphasised by scholars and the financial sector and is not an essential factor for growth (Kassim, 2016).

The supply-leading hypothesis stressed the importance of the establishment of financial institutions over the demand for financial services, particularly in the growth-inducing sector (Patrick, 1966). The proponents of this hypothesis argued that the financial sector, particularly financial intermediaries, is the essential element for economic growth. Its services, such as savings mobilisation, monitoring and risk management, as well as transaction facilities, are essential to support technological advancement and innovation which, in turn, will trigger economic growth (Schumpeter, 1983).

The emergence of financial institutions that mobilised capital is believed to have been the starting point of the Industrial Revolution in England (Levine, 2013). Following studies by Shaw (1973) and McKinnon (1973), financial repression, which was marked by government intervention in financial institutions as mainstream policy in the 1960s and 1970s, came under intense criticism, leading to a shift towards financial liberalisation (Andersen \& Tarp, 2003).

Patrick (1966) highlighted two functions of financial services for economic growth from the supply-leading view. First, the allocation of resources from traditional sectors to new sectors. Second, to stimulate and promote new sectors through entrepreneurial enhancement, such that the new sectors will generate economic growth.

According to Todaro and Smith (2015), the financial sector can support economic growth through six channels. First, the financial sector provides a payment system. A payment system includes personal and commercial cheques 
to help economic agents avoid inefficient and risky cash-carrying behaviour in transactions. Second, the financial sector acts as an intermediary to match savers and investors efficiently. Third, the financial sector collects and distributes information regarding economic activities and their financial needs. Fourth, the financial sector allocates credit efficiently by channelling the collected funds into the most profitable assets or projects. Fifth, the financial sector conducts pricing, pooling and trading risk, especially in the case of insurance. Sixth, the financial sector endeavours to increase asset liquidity, especially for long-term project financing or high-value assets.

Another scholar (Levine, 2013) argued that the financial sector has two channels and five main functions for the purpose of accelerating growth. The two channels are i) accumulation of capital, and ii) technological progress. Further, the five main functions undertaken by the financial sector are as follows: First, facilitation of risk amelioration. The financial sector, including banks, helps to link savers requiring liquid savings with borrowers that need long-term capital investment. Second, reducing the cost of information for resource allocation. The financial sector helps many savers to acquire information about investments from various projects. Thus, information acquisition becomes more efficient. Third, the monitoring function to ensure that the projects being financed will yield returns and reduce information and verification cost. Fourth, the mobilisation of savings to multiple investors, right up to low-end investors or households, with efficient transaction costs and reduced information asymmetry. Fifth, enhancing the specialisation of each economic agent, thus creating more transactions and innovation, which in turn will generate growth.

There are three conditions by which the financial sector can enhance economic growth. First, firms and the government should be willing to invest. Second, there is the ability to mobilise savings. Third, savings should be channelled to entities (firms or government) whose investments pose the most attractive opportunity (Dornbusch \& Reynoso, 1989). Furthermore, good institutional quality is also an important prerequisite for a positive and significant impact of the financial sector on economic growth. A study by Law, Azman-Saini, and Ibrahim (2013) using threshold regression found that among the 85 countries during the period being studied (1980-2008), there was a significant threshold effect of institutional quality (such as corruption, rule of law and bureaucratic quality) on the financegrowth nexus. In countries where the quality of financial institutions was below the threshold, financial development had an insignificant impact on economic growth, while in countries where the quality of insitutions was above the threshold, financial development had a significant and positive impact on economic growth.

\section{Islamic Banking and Economic Growth}

Conceptually, the Islamic financial system promotes the profit-sharing mechanism, which links financial development to real-sector performance, such that equitable income distribution, social justice and long-term economic growth can be attained. The aforementioned principle is applied, especially by Islamic banks as a financial intermediary with their depositors and debtors, which in turn will enhance investment and the efficient allocation of resources, thus making sustainable 
development attainable (Goaied \& Sassi, 2010; Kassim, 2016). This is different from the interest-based banking system in which security is typically oriented based on the objective of securing the capital owner's capital and profit. Islamic banks, through schemes such as mudaraba and murabaha, may significantly enhance economic growth (Nakagawa, 2009).

\subsection{Previous Studies}

Several empirical studies have attempted to prove the connection between the development of the Islamic financial sector and economic growth. Lebdaoui and Wild (2016) observed the relationship between economic growth and the presence of Islamic banking in South East Asian nations with a notable Muslim population, including Indonesia, Malaysia, Singapore, Thailand, Philippines, Brunei and Bangladesh. Utilising quarterly data from 2000 to 2012 and the panel ARDL method, their study employed variables such as Islamic to conventional banks' assets and deposit ratios to represent Islamic banking presence and other control variables (inflation, government spending, FDI, Muslim population, trade openness, etc.) as regressors against economic growth, proxied by real GDP. The study found that the emergence of Islamic banks in South East Asian countries, as represented by both ratios, had a positive effect on economic growth in the region.

Furqani and Mulyany (2009), meanwhile, set out to observe the impact of Islamic bank financing on Malaysia's economy. Employing data from the first quarter of 1997 to Q1 to fourth quarter of 2005 and using the VECM method, this study found that Islamic bank financing positively affected economic growth (measured by real GDP) and capital accumulation (measured by GFCF) in Malaysia. However, they found no long-run cointegration between Islamic bank financing and trade development (measured by exports plus imports) in Malaysia.

The Malaysian case of the issue was also observed by (Kassim, 2016) in a study using the ARDL method and quarterly data from 1998 to 2013, with the Industrial Production Index (IPI) to represent economic growth, followed by explanatory variables such as Islamic bank financing (IBF), Islamic bank deposit (IBD) and various control variables, i.e. government consumption spending (GCE), openness to trade (OPN), gross fixed capital formation (GFCF) and inflation (INF). The study found that Islamic bank deposits in Malaysia supported long-run economic growth while Islamic bank financing affected Malaysia's economic growth in both the short run and long run, with the long-run effect found to be higher.

Another study on the Malaysian case was conducted by Alaabed and Masih (2016) using a threshold regression model to determine the extent of the threshold effect of financial development on the Malaysian economy. The authors found that Malaysia's financial system, which is dominated by interest-bearing and debt-based credit schemes, experienced a threshold effect, i.e. a negative impact of financial development on economic growth once the level of domestic credit reached $24.45 \%$ of GDP. The paper called for a reform of Islamic finance in Malaysia as a means of providing more risk sharing-based financing schemes to stabilise the financial system within the Malaysian economy.

For the case of Indonesia, Abduh and Omar (2012) observed the connection between the Islamic financial sector and economic growth. Their study employed 
data from 2003:Q1 to 2010:Q2 on a quarterly basis, with Islamic bank financing as a proxy for Islamic financial development and two variables to represent economic growth (GDP and GFCF). The study found that Islamic bank financing had a bidirectional and positive connection with Indonesia's economic growth in the long run.

Another study was conducted by Abduh and Chowdhury (2012) in Bangladesh. Taking data from the first quarter of 2004 to the second quarter of 2011, this study used VECM to assess the connection between Islamic bank development, as represented by total financing (TF) and total deposits (TD) of Islamic banks, and economic growth (GDP). The statistical evidence they obtained showed that Islamic bank financing positively affects economic growth in both the long run and the short run. However, the direction of the relationship appeared to be bidirectional.

Based on the above literature, it is found that the majority of studies concluded that, in the context of an economy with Islamic banking, the financial-growth nexus typically supports the supply-leading or mutually dependent hypothesis. However, none of the studies conducted a sectoral-level analysis, which will be included in this study.

\section{DATA AND METHODOLOGY}

\subsection{Data}

The empirical analysis in this study explores the factors and dynamics of overall and sectoral growth of the economy with the financial-growth nexus framework, by employing data from the first quarter of 2007 (2007Q1) to the fourth quarter of 2018 (2018Q4). A total of 48 data points will therefore be used for the data analysis. The study estimates four models that cover Malaysia's overall economy and three economic sectors, namely: 1) the Agriculture sector (AGRI), comprising only the agriculture sub-sector; 2) the Industry sector (INDU), comprising the three sub-sectors of i) Manufacturing; ii) Construction and iii) Mining and Quarrying; and 3) the Services sector (SERV), comprising the sub-sectors of i) Electricity and Gas; ii) Water; iii) Wholesale Trade; iv) Retail Trade; v) Motor Vehicles; vi) Accommodation; vii) Food and Beverage; viii) Transport and Storage; ix) Information \& Communication; x) Finance; xi) Insurance; xii) Real Estate and Business Services; xiii) Government Services; and xiv) Other Services.

Each model has four variables, which were selected based on the model development as mentioned in the next sub-section and data availability. First, Real Gross Domestic Product (GDP) of Malaysia (Y). This is a dependent variable derived from quarterly data obtained from the database of the Department of Statistics Malaysia, with 2010 as the base year. It is used as a measure of the size of Malaysia's economy, comprising all sectors.

Second, Real Gross Fixed Capital Formation (GFCF) of Malaysia (K). This is an independent variable derived from quarterly data obtained from the database of Department of Statistics Malaysia, with 2010 as the base year. It is used as a proxy for fixed capital.

Third, employed labour in Malaysia (L). This is an independent variable derived from quarterly data from the database of the Department of Statistics Malaysia. It measures the amount of labour engaged in the economy and currently employed. 
Fourth, Malaysia's Islamic Bank Financing (IBF). This is an independent variable derived from quarterly data obtained from the database of Bank Negara Malaysia and measures the outstanding financing channelled by Islamic banks to economic sectors in Malaysia.

This study contains both overall and sectoral analyses, comprising three economic sectors: agriculture, industry and services. The sectoral focus of this study is based on Chakraborty (2008). However, the sectoral classifications follow the classifications contained in the Bank Negara Malaysia database. From the previous literature, it is expected that Islamic financial development, as proxied by Islamic bank financing, will enhance economic growth at both the overall and sectoral levels.

\subsection{Model Development}

This study aims to establish models of the financial-growth nexus in the Islamic banking industry within the Malaysian economy, at both the overall and sectoral levels. The previous chapter discussed the possible relationships between the development of Islamic banking and economic growth. As specified by the nature of the data, the Autoregressive Distributed Lag (ARDL) approach is chosen as a suitable method for empirical analysis since it is suitable for estimation with variables that have different orders of integration, whether these consist of only $\mathrm{I}(1)$, only $\mathrm{I}(0)$, are mixed or are mutually cointegrated (Abduh \& Omar, 2012; Kassim, 2016; Pesaran, Shin, \& Smith, 2001).

The models utilised in this study are based on the Cobb-Douglas production function augmented by the Solow (1956) framework. The framework states that the output of the economy is determined by factor inputs (capital and labour), as shown below:

$$
Y=f(K, L)
$$

The output, however, is subject to the technological progress that the nation has achieved. The basic model of the Cobb-Douglas production function with the Solow (1956) framework is shown below:

$$
Y_{t}=A_{t} \cdot K_{t}^{\alpha} \cdot L_{t}^{\beta}
$$

From the above equation, at time $t, Y_{t}$ is the output of the economy, $K_{t}$ is capital stock, $L_{t}$ is the labour force and $A_{t}$ is the stock of technology. The Schumpeterian theory of growth suggests that financial development can enhance technological progress through the provision of services, such as savings mobilisation, monitoring and risk management, as well as transaction facilities (Schumpeter, 1983). Therefore, the stock of technology is a function of financial development $\left(\mathrm{FIN}_{\mathrm{t}}\right)$ :

$$
A_{t}=f\left(F I N_{t}\right)=F I N_{t}^{\phi}
$$


The augmented production function with the inclusion of financial development then becomes:

$$
Y_{t}=K_{t}^{\alpha} \cdot L_{t}^{\beta} \cdot F I N_{t}^{\phi}
$$

In this study, $\mathrm{Y}_{\mathrm{t}}$ is proxied by real GDP, $\mathrm{K}_{\mathrm{t}}$ is proxied by GFCF and $\mathrm{L}_{\mathrm{t}}$ is proxied by the amount of hired labour. Meanwhile, financial development is proxied by Islamic Bank Financing (IBF), as previous studies (Abduh \& Omar, 2012; Furqani \& Mulyany, 2009; Kassim, 2016) have suggested the important role played by the Islamic banking industry in enhancing economic growth through the financing it provides to the economy. The model can thus be rewritten as:

$$
Y_{t}=K_{t}^{\alpha} \cdot L_{t}^{\beta} \cdot I B F_{t}^{\phi}
$$

All variables are transformed into natural logarithm form to see the linear relationship among variables, as shown below:

$$
L Y_{t}=\lambda+\alpha \cdot L K_{t}+\beta \cdot L L_{t}+\phi \cdot L I B F_{t}+\varepsilon_{t}
$$

From the above equation, $\lambda$ is the intercept, $\varepsilon$ is the error term, and $\alpha, \beta$ and $\phi$ are the marginal products of $\mathrm{K}, \mathrm{L}$ and IBF, respectively. This study also includes sectoral analysis. There are thus four models to be estimated, comprising the overall economy and three economic sectors. The model can be modified as follows:

$$
\begin{aligned}
& L Y_{j, t}=\lambda_{j}+\alpha_{j} . L K_{j, t}+\beta_{j} . L L_{j, t}+\phi_{j} . L I B F_{j, t}+\varepsilon_{j, t} \\
& j=(\text { Overall,AGRI,INDU,SERV) }
\end{aligned}
$$

Based on the above theoretical framework, the model estimation in this study is conducted using the ARDL approach, wherein there are three models to estimate for each sectoral analysis based on Pesaran, Shin, and Smith (2001). First, the Restricted Error Correction Model (ECM). The Restricted ECM is shown below:

$$
\begin{aligned}
& \Delta L Y_{j, t}=\lambda_{j, 1}+\sum_{i=1}^{p} \theta_{j, i} \cdot \Delta L Y_{j, t-i}+\sum_{i=0}^{p} \alpha_{j, i} \cdot \Delta L K_{j, t-i}+\sum_{i=0}^{p} \beta_{j, i} \cdot \Delta L L_{j, t-i}+ \\
& \sum_{i=0}^{p} \phi_{j, i} \cdot \Delta L I B F_{j, t-i}+\gamma_{1 j} . L Y_{j, t-1}+\gamma_{2 j} . L K_{j, t-1}+\gamma_{3 j} \cdot L L_{j, t-1}+ \\
& \gamma_{4 j} \cdot L I B F_{j, t-1}+\mu_{j t}
\end{aligned}
$$

From the above equation, $\mathrm{p}$ is the optimum lag and $\Delta$ is the first-difference operator. The existence of a long-run relationship among the variables in equation (8) above is tested by using the F-test, with the following hypotheses tested: 


$$
\begin{aligned}
& H_{0}: \gamma_{1 j}=\gamma_{2 j}=\gamma_{3 j}=\gamma_{4 j}=0 \\
& H_{1}: \gamma_{1 j} \neq \gamma_{2 j} \neq \gamma_{3 j} \neq \gamma_{4 j} \neq 0
\end{aligned}
$$

Given the small sample size of 47 observations in this study, the critical values as formulated by Narayan (2005) that are based on a small sample size are between 30 and 80 . There are two sets of critical values; one set refers to the $\mathrm{I}(0)$ series or lower bound critical values, and the other set refers to the I(1) series or upper bound critical values. An F-test statistic greater than the upper bound values proves there is a long-run relationship among variables regardless of the order of integration of the variables. On the other hand, if the F-test statistic is smaller than the lower bound critical values, the null hypothesis of no cointegration cannot be rejected. If the F-test statistic lies between the bounds, a conclusive inference is only possible by knowing the regressors' order of integration (Duasa, 2007).

Second, the long-run model or cointegration model, which is estimated by establishing the long-run relationship among variables. The long-run model utilised in this study is shown below:

$$
\begin{aligned}
& L Y_{j, t}=\lambda_{j, 2}+\sum_{i=1}^{p} \theta_{j, i} \cdot L Y_{j, t-i}+\sum_{i=0}^{p} \alpha_{j, i} \cdot L K_{j, t-i}+\sum_{i=0}^{p} \beta_{j, i} . L L_{j, t-i}+ \\
& \sum_{i=0}^{p} \phi_{j, i} \cdot L I B F_{j, t-i}+v_{j t}
\end{aligned}
$$

Third, the Unrestricted Error Correction Model (ECM). Unrestricted ECM is utilised by establishing the cointegration model to obtain short-run coefficients. The unrestricted ECMs are shown below:

$$
\begin{aligned}
& \Delta L Y_{j t}=\lambda_{j, 3}+\sum_{i=1}^{p} \theta_{j} . \Delta L Y_{j, t-i}+\sum_{i=1}^{p} \alpha_{j} . \Delta L K_{j, t-i}+\sum_{i=1}^{p} \beta_{j} . \Delta L L_{j, t-i}+ \\
& \sum_{i=1}^{p} \phi_{j} \cdot \Delta L I B F_{j, t-i}+\psi_{j} . E C T_{j, t-1}+\varepsilon_{j t}
\end{aligned}
$$

In the above equation, $\mathrm{p}$ is the optimum lag and ECT stands for Error Correction Term, defined as:

$$
\begin{aligned}
& E C T_{j, t}=L Y_{j, t}-\lambda_{j, 1}-\sum_{i=1}^{p} L Y_{j, t-i}-\sum_{i=0}^{p} \alpha_{j, i} \cdot L K_{j, t-i}-\sum_{i=0}^{p} \beta_{j, i} L L_{j, t-i}- \\
& \sum_{i=0}^{p} \phi_{j, i} L I B F_{j, t-i}
\end{aligned}
$$

A negatively significant ECT is expected as an indication of long-run causality, while significant lag independent variables denote short-run causality (Adebola, Yusoff, \& Dahalan, 2011; Kassim, 2016). If no cointegration is found, the long-run model and unrestricted ECM will not be estimated and only restricted ECM will be presented as an OLS estimation.

Optimum lag length choice is a critical point in ARDL estimation. The optimum lag length can be based on two criteria, either Akaike's Information Criteria (AIC) 
or Schwartz-Bayesian Criteria (SBC). AIC will select a proper and maximum lag length. On the other hand, SBC will choose the smallest (parsimonious) lag possible. In this study, AIC is used to provide more dynamics in the model.

\subsection{Method}

This study conducted a range of statistical tests to analyse the relationship among variables with model estimation as well as to confirm the robustness of the models estimated. In this study, the confidence level of $95 \%(\alpha=0.05)$ is used as a parameter for the significance of the result. Also, statistical tests and model estimations are conducted using EViews 9 software.

The tests include the Phillips-Perron (PP) and Augmented Dickey-Fuller (ADF) tests for stationarity, and bounds testing for cointegration based on Narayan (2005). To ensure the robustness of the models estimated, a total of four diagnostic tests are conducted: i) the Breusch-Godfrey LM test to ensure there is no serial correlation problem in the models; ii) the Breusch-Pagan test to ensure there is no heteroscedasticity problem in the models; iii) the Jarque-Bera test to ensure that the residual error is normally distributed; and iv) the Ramsey RESET test to ensure the models have no misspecification problems.

\section{RESULTS AND ANALYSIS}

\subsection{Results}

\section{Descriptive Statistics}

The descriptive statistics of the variables employed in this study are shown in the table below:

Table 1.

Descriptive Statistics

\begin{tabular}{lcccccc}
\hline Variable & $\begin{array}{c}\text { Unit of } \\
\text { Measurement }\end{array}$ & Mean & Median & Maximum & Minimum & Std. Dev. \\
\hline Y & & $238,101.40$ & $232,850.00$ & $322,600.00$ & $175,876.00$ & $41,090.18$ \\
Y_AGRI & Million RM & $22,138.63$ & $21,950.00$ & $26,700.00$ & $17,778.68$ & $2,301.50$ \\
Y_INDU & & $88,164.28$ & $84,500.00$ & $112,800.00$ & $68,363.24$ & $12,033.19$ \\
Y_SERV & & $127,798.50$ & $125,650.00$ & $184,300.00$ & $83,264.74$ & $27,782.57$ \\
\hline K & & $57,830.90$ & $60,750.00$ & $79,199.73$ & $39,133.60$ & $13,350.28$ \\
K_AGRI & Million RM & $1,994.46$ & $2,029.06$ & $2,653.24$ & $1,378.87$ & 424.03 \\
K_INDU & & $21,707.17$ & $24,354.91$ & $28,887.13$ & $12,750.40$ & $5,615.31$ \\
K_SERV & & $34,143.37$ & $34,366.03$ & $47,659.10$ & $23,230.02$ & $7,481.94$ \\
\hline L & & $12,848.32$ & $12,991.25$ & $14,891.80$ & $10,458.59$ & $1,488.99$ \\
L_AGRI & Thousands of & $1,582.40$ & $1,588.10$ & $1,762.30$ & $1,389.70$ & 106.10 \\
L_INDU & People & $3,416.84$ & $3,546.70$ & $3,938.80$ & $2,823.10$ & 353.70 \\
L_SERV & & $7,849.09$ & $7,881.20$ & $9,473.00$ & $5,900.70$ & $1,082.81$ \\
\hline IBF & & 268.77 & 240.92 & 540.35 & 79.55 & 144.93 \\
IBF_AGRI & & 7.15 & 5.10 & 15.63 & 2.48 & 4.73 \\
IBF_INDU & Million RM & 29.94 & 26.40 & 61.24 & 12.11 & 14.33 \\
IBF_SERV & & 231.68 & 209.53 & 463.49 & 64.47 & 126.18 \\
\hline
\end{tabular}


The above table shows that the size of the Malaysian economy, as represented by GDP (Y), ranges between RM 175.88 billion and RM 322.6 billion within the studied period, with RM 238.1 billion on average and a standard deviation of RM 41.1 billion. Meanwhile, the GDP of the agriculture sector (Y_AGRI) ranges between RM 17.8 billion and RM 26.7 billion, with RM 22.1 billion on average and a standard deviation of RM 2.3 billion. For the industry sector, GDP (Y_INDU) within the studied period ranges between RM 68.4 billion and RM 112.8 billion, with RM 88.2 billion on average and a standard deviation of RM 12 billion. Lastly, GDP in the services sector (Y_SERV) has a mean of RM 127.8 billion, ranges between RM 83.3 billion and RM 184.3 billion and has a standard deviation of RM 27.8 billion. The following figure depicts the trend of the GDP-related variables, as shown below:

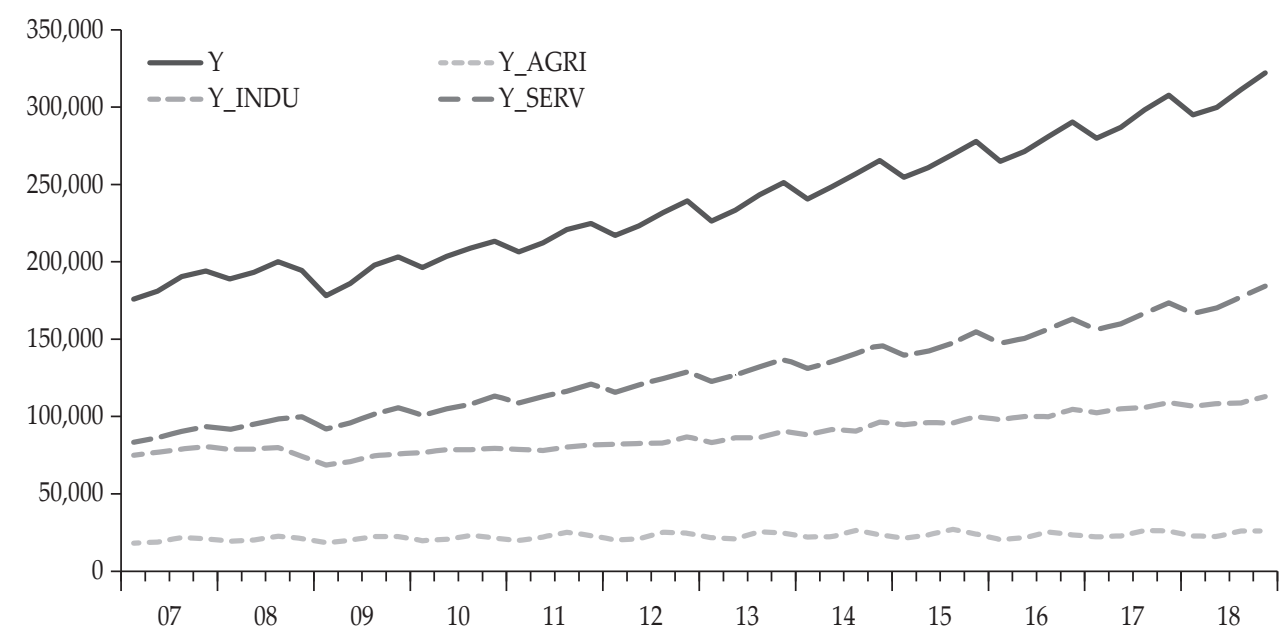

Figure 1.

The Trend of GDP (Y) Related Variables

The above figure shows that the Malaysian economy grew over time during the period of study. This growth was driven mainly by the services sector and industry sector, with the former having the highest share in the economy; however, both sectors grew steadily during the period studied. Meanwhile, the agriculture sector was relatively stagnant compared to the other sectors during the period studied, although it did experience frequent fluctuations within that period.

On the GFCF (K) related variables, Table 4.1 shows that GFCF in the Malaysian economy $(\mathrm{K})$ within the studied period ranged between RM 39.1 billion and RM 79.2 billion, with an average of RM 57.8 billion and a standard deviation of RM 13.4 billion. Meanwhile, the GFCF of the agriculture sector (K_AGRI) ranged between RM 1.4 billion and RM 2.7 billion, with RM 2 billion on average and a standard deviation of RM 0.4 billion. For the industry sector, GFCF (K_INDU) within the studied period ranged between RM 12.8 billion and RM 28.9 billion with RM 21.7 billion on average and a standard deviation of RM 5.6 billion. Lastly, GFCF in the 
services sector (K_SERV) has a mean of RM 34.1 billion, ranges between RM 23.2 billion and RM 47.7 billion and has a standard deviation of RM 7.5 billion. The following figure depicts the trend of the GFCF related variables:

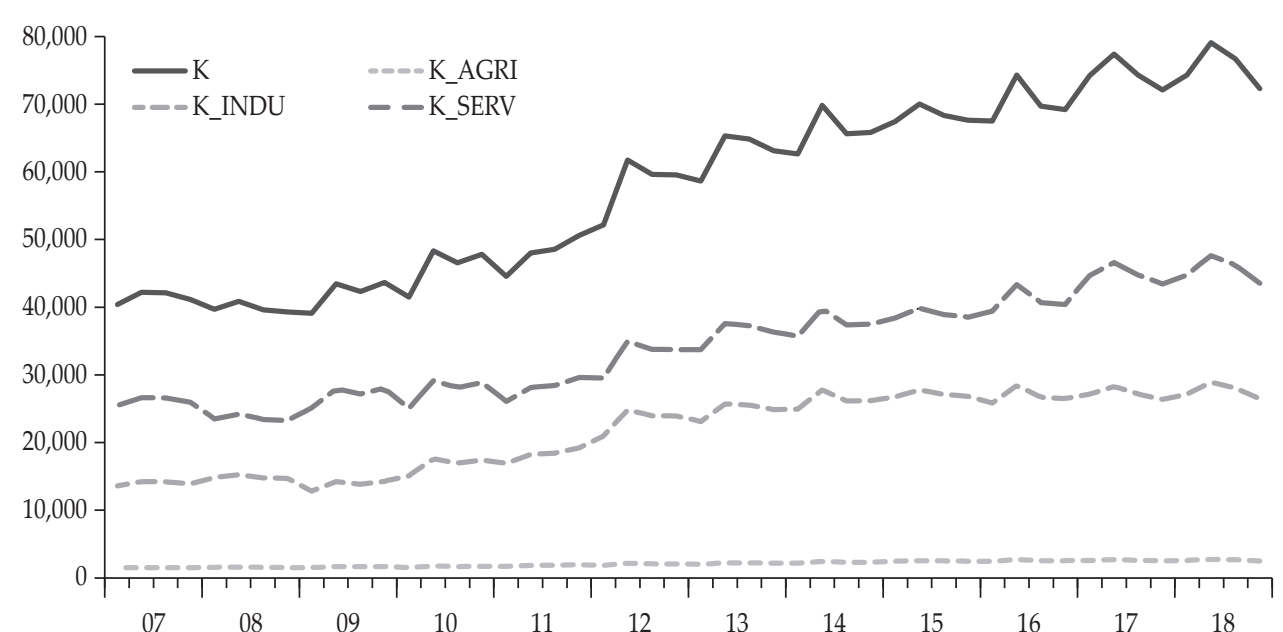

Figure 2.

The Trend of GFCF (K) Related Variables

In the above figure, we see an overall growing trend for GFCF in the Malaysian economy during the period under study, albeit with some fluctuations. The principal contributors to this trend are the services and industry sectors. Meanwhile, the agriculture sector shows a relatively stagnant GFCF within the studied period.

For the labour force (L) related variables, Table 4.1 shows that employed labour in the Malaysian economy (L) within the studied period ranged between 10.5 million and 14.9 million people, with 12.8 million people on average and a standard deviation of 1.5 million people. Meanwhile, hired labour in the agriculture sector (L_AGRI) ranged between 1.4 million and 1.8 million people, with 1.6 million people on average and a standard deviation of 106.100 thousand people. In the industry sector, the labour employed (L_INDU) during the studied period ranged between 2.8 million and 3.9 million people, with 3.4 million people on average and a standard deviation of 353,700 people. Lastly, labour employed in the services sector (L_SERV) has a mean of 7.8 million people and ranges between 5.9 million and 9.5 million people, with a standard deviation of 1.1 million people. The following figure depicts the trend of the labour related variables: 


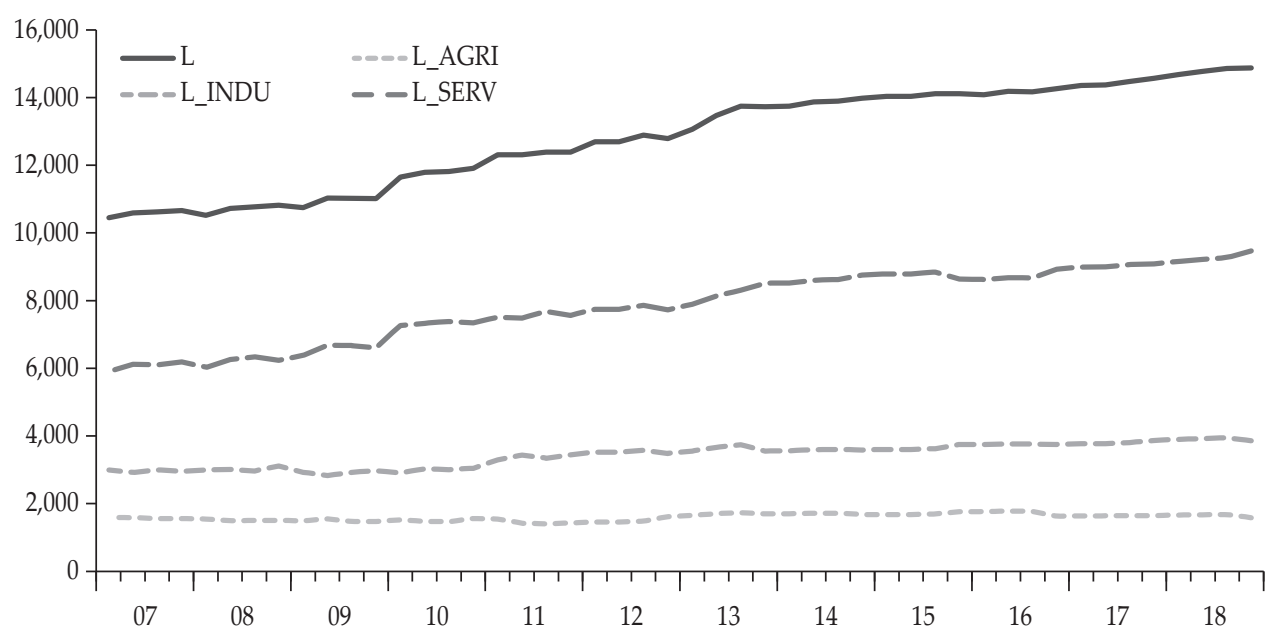

Figure 3.

The Trend of Labour (L) Related Variables

The above figure shows there is a growing trend of employed labour in the Malaysian economy, supported by the growing industry sector and services sector, the former of which has a lower nominal labour employment and growth rate. The agriculture sector accounts for the lowest share in labour employment and is relatively stagnant compared to the other sectors.

For the Islamic Bank Financing (IBF) related variables, Table 4.1 shows that IBF in the Malaysian economy (IBF) within the studied period ranged between RM 79.6 million and RM 540.4 million, with RM 268.8 million on average and a standard deviation of RM 144.9 million. Meanwhile, IBF of the agriculture sector

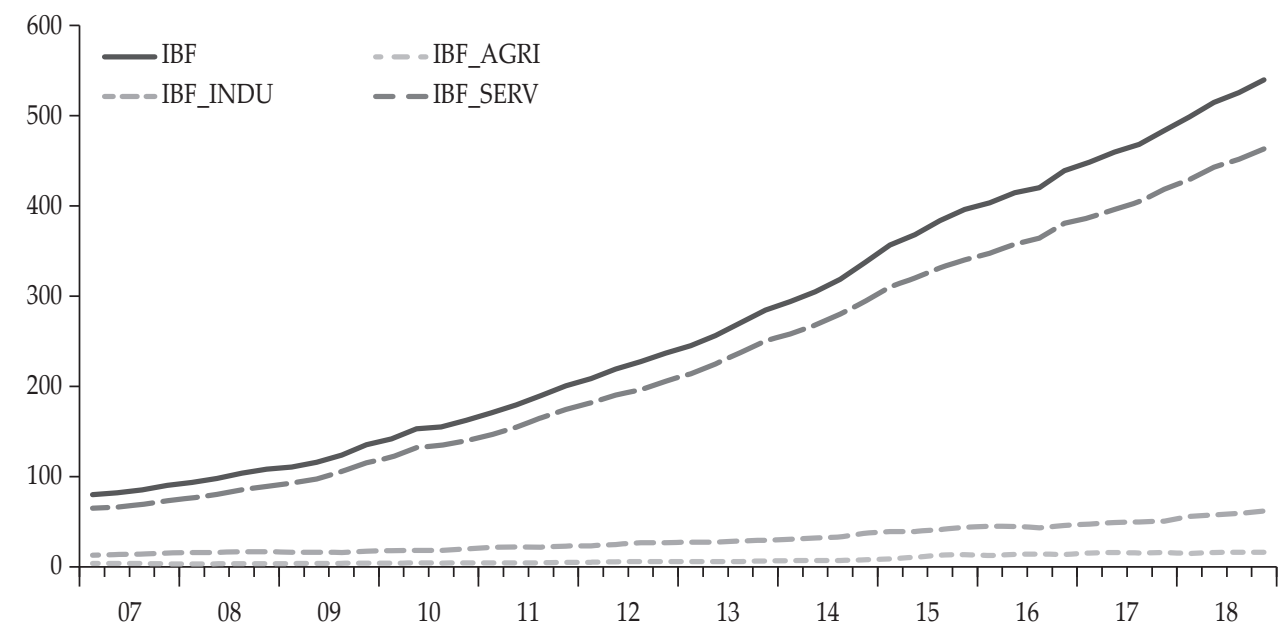

Figure 4.

The Trend of Islamic Bank Financing (IBF) Related Variables 
(IBF_AGRI) ranged between RM 2.5 million and RM 15.6 million, with RM 7.2 million on average and a standard deviation of RM 4.7 million. IBF in the industry sector (IBF_INDU) within the studied period ranged between RM 12.1 million and RM 61.2 billion, with RM 30 million on average and a standard deviation of RM 14.3 million. Lastly, IBF in the services sector (IBF_SERV) has a mean of RM 231.7 billion and ranges between RM 64.5 million and RM 463.5 million with a standard deviation of RM 126.2 million. The following figure depicts the trend of the IBF related variables:

The figure above shows that IBF in Malaysia underwent rapid growth during the period under study, with the main contribution by the services sector. While there was also a growing trend for IBF in the industry and agriculture sectors, their rates of growth and nominal levels are relatively low compared to the services sector.

In general, within the studied period, the services sector is dominant within the Malaysian economy, not only in terms of GDP but also other variables including physical capital investment (GFCF), employed labour and Islamic bank financing.

\section{Unit Root Tests}

Unit roots tests are conducted in this study to ensure stationarity of the variables, to avoid spurious regressions (Asteriou \& Hall, 2007) and to ensure no I(2) variables, which may result in invalid ARDL estimations. In other words, the variables may be integrated first difference $(\mathrm{I}(1)$ ) or at level (I(0)) (Kassim, 2016).

Before the stationarity tests, the plots of all the variables are checked to confirm the existence of constant and trend in their movement. All variables with log form are shown to have trend and intercept in their plot, which means the constant and linear trends were included in both tests. Meanwhile, the plots of variables measured as percentages are shown to have intercept only, so constant is added. The results of the stationarity tests with ADF and PP methods are summarised in the following table:

Table 2.

Unit Root Tests Results

\begin{tabular}{lcccc}
\hline \multirow{2}{*}{ Variable } & \multicolumn{2}{c}{ ADF } & \multicolumn{2}{c}{ PP } \\
\cline { 2 - 5 } & At Level & First Difference & At Level & First Difference \\
\hline LY & $-5.62604^{*}$ & $-3.978025^{*}$ & $-4.45845^{*}$ & $-12.60853^{*}$ \\
LYAGRI & $-2.632309^{*}$ & $-4.851190^{*}$ & $-6.5877^{*}$ & $-10.79409^{*}$ \\
LYINDU & -2.30305 & $-4.92029^{*}$ & -2.0209 & $-11.4564^{*}$ \\
LYSERV & $-3.970842^{*}$ & $-5.841360^{*}$ & $-7.629527^{*}$ & $-19.07961^{*}$ \\
LK & -2.11564 & $-6.03304^{*}$ & -2.92238 & $-14.119^{*}$ \\
LKAGRI & -2.20475 & $-7.44612^{*}$ & $-3.696776^{*}$ & $-13.83463^{*}$ \\
LKINDU & -1.08063 & $-5.26445^{*}$ & -1.38695 & $-8.12305^{*}$ \\
LKSERV & $-3.668496^{*}$ & $-5.935408^{*}$ & $-3.88932^{*}$ & $-15.42300^{*}$ \\
LL & -0.87881 & $-5.53956^{*}$ & -1.03827 & $-7.5605^{*}$ \\
LLAGRI & -2.19187 & $-5.15891^{*}$ & -2.17793 & $-6.08751^{*}$ \\
LLINDU & -1.97199 & $-6.09815^{*}$ & -2.40606 & $-7.69016^{*}$ \\
\hline
\end{tabular}


Table 2.

Unit Root Tests Results (Continued)

\begin{tabular}{lcccc}
\hline \multirow{2}{*}{ Variable } & \multicolumn{2}{c}{ ADF } & \multicolumn{2}{c}{ PP } \\
\cline { 2 - 5 } & At Level & First Difference & At Level & First Difference \\
\hline LLSERV & -1.36693 & $-5.97633^{*}$ & -1.88546 & $-8.71616^{*}$ \\
LIBF & 0.456801 & $-4.3349^{*}$ & 0.908705 & $-6.40208^{*}$ \\
LIBFAGRI & -2.8244 & $-4.14552^{*}$ & -2.69048 & $-5.89471^{*}$ \\
LIBFINDU & -2.81992 & $-5.53012^{*}$ & -2.5132 & $-8.07534^{*}$ \\
LIBFSERV & 0.979943 & $-4.520371^{*}$ & 0.778626 & $-6.515956^{*}$ \\
\hline
\end{tabular}

t-statistic followed by p-value in ( )

*denotes significance at $\alpha=0.05$

The table above shows that all variables have a consistent order of integration in both $\mathrm{ADF}$ and PP tests, either I(0) or I(1). In other words, no variable has the order of integration at the second difference, and given the different order of integration among variables, this condition confirms that ARDL is the appropriate method for use in this study.

\section{Bounds Testing for Cointegration}

Bounds testing for cointegration is conducted to check for the existence of longrun equilibrium among variables in the ARDL models. The results of the bounds testing for cointegration and critical values from Narayan (2005) at the 95\% confidence level are shown below:

Table 3.

Results of Bounds Test for Cointegration

\begin{tabular}{lcc}
\hline & & Lag of ARDL dynamic regressors (Y, \\
Sector & F-Statistic & K, L, IBF) \\
\hline Overall Economy & $6.543932^{*}$ & $(5,1,1,1)$ \\
Agriculture & $5.758139^{*}$ & $(4,1,0,0)$ \\
Industry & 2.119867 & $(1,0,0,1)$ \\
Services & $9.81238^{*}$ & $(1,0,7,0)$ \\
\hline Upper bound $(\mathrm{I}(1))$ & 4.733 & \\
Lower bound $(\mathrm{I}(0))$ & 3.535 & \\
No. of independent variables & 3 &
\end{tabular}

The above table shows that in the overall economy, agriculture sector and services sector, the F-statistic exceeds the upper bound critical value. This indicates there is no long-run relationship among the variables as the null hypothesis can be rejected. This finding implies that all of the variables have a long-run relationship with each other. However, cointegration is not found in the industry sector because the F-statistic does not exceed the upper bound critical value. 


\section{Main Models}

The complete main model estimations are shown in the appendices. The following table contains a summary of the results of the model estimation, with a focus on the impact of IBF on economic growth.

Table 4.

Summary of Main Model Results with Focus on IBF Impact

\begin{tabular}{lccc}
\hline \multirow{2}{*}{ Sector } & \multicolumn{2}{c}{ Short Run } & \multirow{2}{*}{ Long Run } \\
\cline { 2 - 3 } & Direction & Lag(s) & \\
\hline Overall & Positive & 0 & Positive \\
Agriculture & Negative & 0 & Negative \\
Industry & Positive & 0 & Not found \\
Services & Positive & 0 & Positive \\
\hline
\end{tabular}

With significance at $\alpha=0.05$

The above table indicates that IBF affects Malaysia's overall economic growth in a positive direction in both the long run and short run, while a similar pattern is also found in the services sector. For the industry sector, IBF is found to be significant in the short run in a positive direction, but no long-run relationship is found due to the non-existence of cointegration. There is a different result for the agriculture sector, the growth in which is significantly and negatively affected by IBF in both the short run and the long run.

\subsection{Robustness Test}

To ensure the robustness of the models estimated, various diagnostic tests are taken with the following results:

Table 5.

Results of Diagnostic Tests

\begin{tabular}{lllll}
\hline Sector & $\begin{array}{c}\text { Breusch- } \\
\text { Godfrey Serial } \\
\text { Correlation } \\
\text { (Chi-Square) }\end{array}$ & $\begin{array}{c}\text { Harvey } \\
\text { Heteroscedasticity } \\
\text { (Chi-Square) }\end{array}$ & $\begin{array}{c}\text { Jarque-Bera } \\
\text { Normality (JB-Stat) }\end{array}$ & $\begin{array}{c}\text { Ramsey RESET } \\
\text { (F-Stat) }\end{array}$ \\
\hline Overall & 1.195437 & 3.512603 & 0.6745 & 2.72897 \\
Economy & $(0.5501)$ & $(0.1727)$ & $(0.7137)$ & $(0.2555)$ \\
\hline Agriculture & 11.50845 & 14.55987 & 3.134155 & 15.69342 \\
& $(0.4017)$ & $(0.0683)$ & $(0.6973)$ & $(0.1529)$ \\
\hline \multirow{2}{*}{ Industry } & 0.47424 & 1.46293 & 3.797676 & 0.619483 \\
\hline \multirow{2}{*}{ Services } & $(0.77625)$ & $(0.4812)$ & $(0.14974)$ & $(0.73364)$ \\
\hline
\end{tabular}

t-statistic followed by p-value in ( )

*denotes significance at $\alpha=0.05$ 
The above table shows that no model has significant diagnostic test statistics. In other words, no diagnostic problem is found in any of the models and it can thus be concluded that all models are robust and correctly specified.

\subsection{Analysis}

Areas of the findings from this research, particularly with regard to the agriculture sector, appear to differ from the findings of previous studies (Abduh \& Omar, 2012; Furqani \& Mulyany, 2009; Kassim, 2016), all of which concluded that IBF positively and significantly affects economic growth, in both the short run and the long run. However, the findings of this study for other models are more in line with the previous studies and also a study by Chakraborty (2008) in the case of the industry and services sectors in India.

There are three possible explanations for the above findings. First, Patrick (1966) stated that financial services tend to allocate resources from non-growth and traditional sectors to boost growth-induced and modern sectors. It is inferred that Islamic banking in Malaysia operates with a similar tendency, transferring resources from the agriculture sector, as a traditional and non-growth sector, to the industry and services sectors, which are modern and growth-induced sectors with a dominant share of Malaysia's economy. This is in line with the current state of the Malaysian economy that is dominated by the positively growing services sector, while the agriculture sector has the lowest share in the economy and has experienced negative growth in certain periods.

Second, referring to Alaabed and Masih (2016), it is possible that the negative impact of IBF on the growth of the agriculture sector is due to the utilisation of debt-based financing contracts in the agriculture sector, with the tendency for this to divert resources away from the productive sector (agriculture sector, in this regard). Therefore, a sharia-compliant risk-sharing mechanism must be promoted to solve this problem.

Third, two studies, from Gazdar and Cherif (2015) in the case of 18 MENA (Middle East and North Africa) countries, and Hasan, Wachtel, and Zhou (2009) in China, yielded quite similar results, concluding that poor institutional quality and bad banking practices led to a negative impact of financial development on economic growth. Also, Law et al. (2013) found that good institutional quality, particularly related to corruption, rule of law and bureaucratic quality, can determine the effect of financial development on economic growth. In other words, there is a possibility that Islamic banks in Malaysia do not manage their financing for the agriculture sector as well as they do for other sectors, which may create a negative impact of IBF on the agriculture sector; alternatively, the quality of the institutions that regulate the agricultural sector in Malaysia may not be as good as in other economic sectors. 


\section{CONCLUSION AND RECOMMENDATIONS}

\subsection{Conclusion}

This study has focused on empirical analysis to reveal any evidence of the finance-growth nexus in the Islamic banking industry within the Malaysian economy, at both the overall and sectoral levels in the short run and long run.

The study used the ARDL approach to investigate the nexus. Between 2007Q1 and 2018Q4, the ARDL models estimated in this study found that the financegrowth nexus in the Islamic banking industry within the Malaysian economy displayed different patterns at the overall level and across sectors despite the existence of cointegration, while some were quite different from previous studies.

For the overall economy and services sector, Islamic bank financing significantly affects economic growth in a positive direction in the long run and short run. The positive impact of Islamic bank financing on economic growth is also found in the industry sector, but only in the short run. Meanwhile, Islamic bank financing to the agriculture sector is found to negatively affect the growth of that sector in both the short run and long run.

\subsection{Recommendations}

For policymakers, particularly the government of Malaysia and BNM, given the result of this study, the VBI initiative already underway should prioritise Islamic financing to the agriculture sector since this sector is found to be negatively affected by Islamic bank financing. Although the agriculture sector accounts for only a relatively small proportion of the Malaysian economy, its importance as a producer of food (i.e. rice) and export-oriented commodities (i.e. rubber and palm oil) should be supported by an appropriate Islamic financing scheme.

Islamic bankers should also take VBI more seriously in terms of handling their financing to the agriculture sector to turn the potential negative long-term impact, as shown by this study, into a positive one. The utilisation of Islamic financing contracts that relate directly to agriculture, such as salam and muzara'ah, have the potential to become a vehicle of community empowerment in the agriculture sector in Malaysia and create a positive impact of Islamic bank financing on the agriculture sector. Also, priority should be given to improving the institutional quality of Islamic banks and to the prevention of bad banking practices to ensure that Islamic banks support Malaysia's economic growth in both the short run and long run.

This study has some limitations. First, it covers only Islamic bank financing as a representation of Islamic finance. Future studies should thus consider other parts of the Islamic financial services universe, such as the Islamic capital market, takaful, Islamic funds and so on as a proxy for Islamic financial development, in order to provide a comprehensive view of the impact of Islamic finance on the economy.

Second, the analysis of economic growth in this study does not cover the business cycles that occurred during the period under study. Therefore, including the business-cycle element in the model estimation would be a good way to produce a more comprehensive result. 
Third, this study covers only the case of Malaysia. As such, a cross-country comparison and panel data analysis of the finance-growth nexus in the context of Islamic finance could also be considered, given the rapid development of the Islamic financial industry in recent decades in various countries, in order to derive the global pattern of the finance-growth nexus in the Islamic finance universe. This cross-country analysis may also reveal differences between fully Islamic finance and dual financial systems among nations.

Fourth, future studies may consider analysing the institutional quality in each economic sector to obtain a more comprehensive and better model for capturing the impact of Islamic banking on economic growth in Malaysia.

\section{REFERENCES}

Abduh, M., \& Chowdhury, N. (2012). Does Islamic Banking Matter for Economic Growth in Bangladesh. Journal of Islamic Economics, Banking and Finance, 8(3), 104-113. Retrieved from http://ibtra.com/pdf/journal/ v8\%7B_\%7Dn3\%7B_\%7Darticle6.pdf

Abduh, M., \& Omar, M. A. (2012). Islamic Banking and Economic Growth: The Indonesian Experience. International Journal of Islamic and Middle Eastern Finance and Management, 5(1), 35-47.

Adebola, S. S., Yusoff, W. S. b. W., \& Dahalan, J. (2011). An ARDL Approach to the Determinants of Non-Performing Loans in Islamic Banking System in Malaysia. Arabian Journal of Business and Management Review, 1(2), 20-30.

Alaabed, A., \& Masih, M. (2016). Finance-Growth Nexus: Insights from An Application of Threshold Regression Model to Malaysia's Dual Financial System. Borsa Istanbul Review, 16(2), 63-71. https://doi.org/10.1016/j. bir.2016.01.004

Andersen, T. B., \& Tarp, F. (2003). Financial Liberalization, Financial Development and Economic Growth in LDCs. Journal of International Development, 15, 189209. https://doi.org/10.1002/jid.971

Asteriou, D., \& Hall, S. G. (2007). Applied Econometrics, A Modern Approach (Revised Edition). New York: Palgrave Macmillan.

Bank Negara Malaysia (2018). The Financial Stability and Payment Systems Report 2018. Kuala Lumpur.

Chakraborty, I. (2008). Does Financial Development cause Economic Growth? The Case of India. South Asia Economic Journal, 9(1), 109-139. https://doi. org $/ 10.1177 / 139156140700900105$

Department of Statistics Malaysia (2019), Gross domestic product Malaysia, fourth quarter 2018.

Dornbusch, R., \& Reynoso, A. (1989). Financial Factors in Economic Development. American Economic Review, 79(2), 204-209.

Duasa, J. (2007). Determinants of Malaysian Trade Balance: An ARDL Bound Testing Approach. Global Economic Review, 36(1), 89-102. https://doi. org/10.1080/12265080701217405

Furqani, H., \& Mulyany, R. (2009). Islamic Banking and Economic Growth: Empirical Evidence from Malaysia. Journal of Economic Cooperation and Development, 30(2), 59-74. https://doi.org/10.1017/CBO9781107415324.004 
Gazdar, K., \& Cherif, M. (2015). Institutions and The Finance-Growth Nexus: Empirical Evidence from MENA Countries. Borsa Istanbul Review, 15(3), 137160. https://doi.org/10.1016/j.bir.2015.06.001

Goaied, M., \& Sassi, S. (2010). Financial Development and Economic Growth in the MENA Tegion: What about Islamic Banking Development.

Hasan, I., Wachtel, P., \& Zhou, M. (2009). Institutional Development, Financial Deepening and Economic Growth: Evidence from China. Journal of Banking and Finance, 33(1), 157-170. https://doi.org/10.1016/j.jbankfin.2007.11.016

Kahf, M. (2007). Islamic Banks and Economic Development. In M. K. Hassan \& M. K. Lewis (Eds.), Handbook of Islamic Banking (pp. 277-284). Cheltenham, UK: Edward Elgar Publishing Limited.

Kassim, S. (2016). Islamic Finance and Economic Growth: The Malaysian Experience. Global Finance Journal, 30, 66-76. Retrieved from http://www. worldbank.org/en/topic/financialsector/brief/islamic-finance

Khan, M. M., \& Bhatti, M. I. (2008). Islamic Banking and Finance: On Its Way to Globalization. Managerial Finance, 34(10), 708-725. https://doi. org/10.1108/03074350810891029

Law, S. H., Azman-Saini, W. N. W., \& Ibrahim, M. H. (2013). Institutional Quality Thresholds and the Finance-Growth Nexus. Journal of Banking and Finance, 37(12), 5373-5381. https://doi.org/10.1016/j.jbankfin.2013.03.011

Lebdaoui, H., \& Wild, J. (2016). Islamic Banking Presence and Economic Growth in Southeast Asia. International Journal of Islamic and Middle Eastern Finance and Management, 9(4), 551-569. https://doi.org/10.1108/IMEFM-03-2015-0037

Levine, R. (2013). Economic Development and Financial and Agenda Growth: Views, 35(2), 688-726.

Lucas, R. E. (1988). On the Mechanics of Economic Development. Journal of Monetary Economics, 22, 3-42.

Memon, N. A. (2007). Islamic Banking: Present and Future Challenges. Journal of Management and Social Sciences, 3(1), 1-10.

Nakagawa, R. (2009). The Evolution of Islamic Finance in Southeast Asia: The Case of Malaysia. The Journal of Applied Business Research, 25(1), 111-126.

Narayan, P. K. (2005). The Saving and Investment Nexus for China : Evidence from Cointegration. Applied Economics, 37, 1979-1990. https://doi. org/10.1080/00036840500278103

Patrick, H. T. (1966). Financial Development and Economic Growth in Underdeveloped Countries. Economic Development and Cultural Change, 14(2), 174-189.

Pesaran, M. H., Shin, Y., \& Smith, R. J. (2001). Bounds Testing Approaches to the Analysis of Level Relationships. Journal of Applied Econometrics, 16(3), 289-326. https://doi.org/10.1002/jae.616

Schumpeter, J. A. (1983). The Theory of Economic Development: An Inquiry into Profits, Capital, Credit, Interest, and the Business Cycle. New Brunswick: Transaction Publishers.

Solow, R. M. (1956). A Contribution to the Theory of Economic Growth. The Quarterly Journal of Economics, 70(1), 65-94.

Thomson Reuters (2018a). Global Islamic Economy Report 2018/19.

Thomson Reuters (2018b). Islamic Finance Development Report 2018. 
Todaro, M. P., \& Smith, S. C. (2015). Economic Development. https://doi. org/10.1177/089124240001400105

Adebola, S. S., Yusoff, W. S. b. W., \& Dahalan, J. (2011). An ARDL Approach to the Determinants of Non-Performing Loans in Islamic Banking System in Malaysia. Arabian Journal of Business and Management Review, 1(2), 20-30.

Alaabed, A., \& Masih, M. (2016). Finance-Growth Nexus: Insights from An Application of Threshold Regression Model to Malaysia's Dual Financial System. Borsa Istanbul Review, 16(2), 63-71. https://doi.org/10.1016/j. bir.2016.01.004

Andersen, T. B., \& Tarp, F. (2003). Financial Liberalization, Financial Development and Economic Growth in LDCs. Journal of International Development, 15, 189209. https://doi.org/10.1002/jid.971

Dornbusch, R., \& Reynoso, A. (1989). Financial Factors in Economic Development. American Economic Review, 79(2), 204-209.

Duasa, J. (2007). Determinants of Malaysian Trade Balance: An ARDL Bound Testing Approach. Global Economic Review, 36(1), 89-102. https://doi. org/10.1080/12265080701217405

Furqani, H., \& Mulyany, R. (2009). Islamic Banking and Economic Growth: Empirical Evidence from Malaysia. Journal of Economic Cooperation and Development, 30(2), 59-74. https://doi.org/10.1017/CBO9781107415324.004

Kassim, S. (2016). Islamic Finance and Economic Growth: The Malaysian Experience. Global Finance Journal, 30, 66-76. Retrieved from http://www. worldbank.org/en/topic/financialsector/brief/islamic-finance

Levine, R. (2013). Economic Development and Financial and Agenda Growth: Views, 35(2), 688-726.

Narayan, P. K. (2005). The Saving and Investment Nexus for China : Evidence From Cointegration. Applied Economics, 37, 1979-1990. https://doi. org/10.1080/00036840500278103

Patrick, H. T. (1966). Financial Development and Economic Growth in Underdeveloped Countries Author(s): Economic Development and Cultural Change, 14(2), 174-189.

Pesaran, M. H., Shin, Y., \& Smith, R. J. (2001). Bounds Testing Approaches to the Analysis of Level Relationships. Journal of Applied Econometrics, 16(3), 289-326. https://doi.org/10.1002/jae.616

Schumpeter, J. A. (1983). The Theory of Economic Development: An Inquiry into Profits, Capital, Credit, Interest, and the Business Cycle. New Brunswick: Transaction Publishers. 


\section{APPENDIX 1}

Estimated Model: Overall Economy

\begin{tabular}{|c|c|c|c|c|}
\hline Variable & Coefficient & Std. Error & t-Statistic & Prob. \\
\hline $\mathrm{D}(\mathrm{LY}(-1))$ & 0.037569 & 0.13072 & 0.287402 & 0.7757 \\
\hline $\mathrm{D}(\mathrm{LY}(-2))$ & -0.11102 & 0.119799 & -0.92672 & 0.3612 \\
\hline D(LY(-3)) & -0.15305 & 0.110287 & -1.38778 & 0.1751 \\
\hline D(LY(-4)) & 0.733536 & 0.102033 & 7.189175 & $0.0000^{*}$ \\
\hline $\mathrm{D}(\mathrm{LK})$ & 0.029924 & 0.072242 & 0.414225 & 0.6816 \\
\hline $\mathrm{D}(\mathrm{LL})$ & 0.325287 & 0.249551 & 1.303485 & 0.202 \\
\hline D(LIBF) & 0.678274 & 0.201807 & 3.36101 & $0.0021^{*}$ \\
\hline CointEq(-1) & -0.29487 & 0.103346 & -2.85327 & $0.0076^{*}$ \\
\hline \multicolumn{5}{|c|}{ Cointeq $=\mathrm{LY}-\left(0.2072^{*} \mathrm{LK}-1.5109^{*} \mathrm{LL}+0.5591^{*} \mathrm{LIBF}+21.2513\right)$} \\
\hline \multicolumn{5}{|c|}{ Long Run Coefficients } \\
\hline Variable & Coefficient & Std. Error & $\mathrm{t}$-Statistic & Prob. \\
\hline LK & 0.207176 & 0.208429 & 0.993987 & 0.3279 \\
\hline LL & -1.51089 & 0.581309 & -2.59912 & $0.0142^{*}$ \\
\hline LIBF & 0.559143 & 0.107632 & 5.194968 & $0.0000^{*}$ \\
\hline $\mathrm{C}$ & 21.25131 & 4.075911 & 5.21388 & $0.0000^{*}$ \\
\hline R-squared & 0.995157 & \multicolumn{2}{|c|}{ Mean dependent var } & 12.393 \\
\hline Adjusted R-squared & 0.993439 & \multicolumn{2}{|c|}{ S.D. dependent var } & 0.160186 \\
\hline S.E. of regression & 0.012975 & \multicolumn{2}{|c|}{ Akaike info criterion } & -5.6206 \\
\hline Sum squared resid & 0.005219 & \multicolumn{2}{|c|}{ Schwarz criterion } & -5.12911 \\
\hline Log likelihood & 132.8429 & \multicolumn{2}{|c|}{ Hannan-Quinn criter. } & -5.43935 \\
\hline F-statistic & 579.1043 & \multicolumn{2}{|c|}{ Durbin-Watson stat } & 1.766102 \\
\hline Prob(F-statistic) & $0.0000^{*}$ & & & \\
\hline
\end{tabular}




\section{APPENDIX 2}

\section{Estimated Model: Agriculture Sector}

\begin{tabular}{|c|c|c|c|c|}
\hline Variable & Coefficient & Std. Error & $\mathrm{t}$-Statistic & Prob. \\
\hline D(LYAGRI(-1)) & 0.154189 & 0.271332 & 0.568269 & 0.5735 \\
\hline D(LYAGRI(-2)) & -0.3615 & 0.180262 & -2.0054 & 0.0527 \\
\hline D(LYAGRI(-3)) & -0.28781 & 0.148664 & -1.93596 & 0.061 \\
\hline D(LKAGRI) & 0.12726 & 0.139424 & 0.912762 & 0.3676 \\
\hline D(LLAGRI) & -0.24396 & 0.129474 & -1.88426 & 0.0679 \\
\hline D(LIBFAGRI) & -0.0756 & 0.035175 & -2.14915 & $0.0386^{*}$ \\
\hline CointEq(-1) & -0.97192 & 0.312178 & -3.11336 & $0.0037^{*}$ \\
\hline \multicolumn{5}{|c|}{ Cointeq = LYAGRI $-\left(0.5547^{*}\right.$ LKAGRI $-0.2510^{*}$ LLAGRI $-0.0778^{*}$ LIBFAGRI +7.7914) } \\
\hline \multicolumn{5}{|c|}{ Long Run Coefficients } \\
\hline Variable & Coefficient & Std. Error & t-Statistic & Prob. \\
\hline LKAGRI & 0.554697 & 0.128321 & 4.322737 & $0.0001^{*}$ \\
\hline LLAGRI & -0.25101 & 0.157725 & -1.59145 & 0.1205 \\
\hline LIBFAGRI & -0.07778 & 0.036341 & -2.1403 & $0.0394^{*}$ \\
\hline $\mathrm{C}$ & 7.791357 & 0.968516 & 8.044631 & $0.0000^{*}$ \\
\hline R-squared & 0.888225 & \multicolumn{2}{|c|}{ Mean dependent var } & 10.01077 \\
\hline Adjusted R-squared & 0.862676 & \multicolumn{2}{|c|}{ S.D. dependent var } & 0.098965 \\
\hline S.E. of regression & 0.036674 & \multicolumn{2}{|c|}{ Akaike info criterion } & -3.59326 \\
\hline Sum squared resid & 0.047074 & \multicolumn{2}{|c|}{ Schwarz criterion } & -3.22831 \\
\hline Log likelihood & 88.0517 & \multicolumn{2}{|c|}{ Hannan-Quinn criter. } & -3.45792 \\
\hline F-statistic & 34.76597 & \multicolumn{2}{|c|}{ Durbin-Watson stat } & 1.710922 \\
\hline Prob(F-statistic) & $0.0000^{*}$ & & & \\
\hline
\end{tabular}

\section{APPENDIX 3}

Estimated Model: Industry Sector

\begin{tabular}{lcccc}
\hline Variable & Coefficient & Std. Error & t-Statistic & Prob. \\
\hline LYINDU(-1) & 0.693332 & 0.120844 & 5.737417 & 0 \\
LKINDU & 0.075393 & 0.053604 & 1.406468 & 0.1671 \\
LLINDU & -0.24393 & 0.151674 & -1.60827 & 0.1154 \\
LIBFINDU & 0.256815 & 0.120929 & 2.123683 & 0.0398 \\
LIBFINDU(-1) & -0.15893 & 0.109974 & -1.44513 & 0.156 \\
C & 4.400843 & 1.588678 & 2.770128 & 0.0084 \\
\hline & \multicolumn{5}{|c}{} \\
\hline R-squared & 0.962803 & Mean dependent var & 11.38134 \\
Adjusted R-squared & 0.958267 & S.D. dependent var & 0.133666 \\
S.E. of regression & 0.027306 & Akaike info criterion & -4.24466 \\
Sum squared resid & 0.030571 & Schwarz criterion & -4.00847 \\
Log likelihood & 105.7496 & Hannan-Quinn criter. & -4.15578 \\
F-statistic & 212.2477 & Durbin-Watson stat & 2.114118 \\
Prob(F-statistic) & $0.0000^{*}$ & & \\
\hline
\end{tabular}




\section{APPENDIX 4}

\section{Estimated Model: Services Sector}

\begin{tabular}{|c|c|c|c|c|}
\hline Variable & Coefficient & Std. Error & $\mathrm{t}$-Statistic & Prob. \\
\hline D(LLSERV) & -0.79762 & 0.313551 & -2.54385 & 0.0166 \\
\hline D(LLSERV(-1)) & 0.304219 & 0.352069 & 0.864087 & 0.3946 \\
\hline D(LLSERV(-2)) & 0.125899 & 0.298396 & 0.421917 & 0.6762 \\
\hline D(LLSERV(-3)) & 0.236852 & 0.304685 & 0.777368 & 0.4432 \\
\hline D(LLSERV(-4)) & 0.013725 & 0.317207 & 0.043269 & 0.9658 \\
\hline D(LLSERV(-5)) & -0.04734 & 0.297525 & -0.1591 & 0.8747 \\
\hline D(LLSERV(-6)) & 0.458784 & 0.263696 & 1.739818 & 0.0925 \\
\hline D(LKSERV) & -0.13861 & 0.124926 & -1.10952 & 0.2763 \\
\hline D(LIBFSERV) & 0.7466 & 0.210265 & 3.550756 & 0.0013 \\
\hline CointEq(-1) & -0.94185 & 0.212698 & -4.42809 & 0.0001 \\
\hline \multicolumn{5}{|c|}{ Cointeq = LYSERV - (-1.5019*LLSERV -0.1472*LKSERV + 0.7927*LIBFSERV + 22.4835) } \\
\hline \multicolumn{5}{|c|}{ Long Run Coefficients } \\
\hline Variable & Coefficient & Std. Error & t-Statistic & Prob. \\
\hline LLSERV & -1.50187 & 0.424729 & -3.53608 & 0.0014 \\
\hline LKSERV & -0.14717 & 0.117964 & -1.24755 & 0.2222 \\
\hline LIBFSERV & 0.792698 & 0.120547 & 6.575858 & 0 \\
\hline $\mathrm{C}$ & 22.48352 & 3.565095 & 6.306569 & 0 \\
\hline R-squared & 0.9829 & \multicolumn{2}{|c|}{ Mean dependent var } & 11.78885 \\
\hline Adjusted R-squared & 0.976414 & \multicolumn{2}{|c|}{ S.D. dependent var } & 0.188759 \\
\hline S.E. of regression & 0.028989 & \multicolumn{2}{|c|}{ Akaike info criterion } & -4.00469 \\
\hline Sum squared resid & 0.024371 & \multicolumn{2}{|c|}{ Schwarz criterion } & -3.50316 \\
\hline Log likelihood & 94.09619 & \multicolumn{2}{|c|}{ Hannan-Quinn criter. } & -3.82206 \\
\hline F-statistic & 151.5359 & \multicolumn{2}{|c|}{ Durbin-Watson stat } & 1.849343 \\
\hline Prob(F-statistic) & $0.0000^{*}$ & & & \\
\hline
\end{tabular}


This page is intentionally left blank 